\title{
Wojciech Lamentowicz
}

Wyższa Szkoła Administracji i Biznesu, Gdynia

wl.667788@gmail.com

ORCID: https://orcid.org/0000-0001-9045-090X

\section{The Emergence of the Legal Order}

\author{
http://dx.doi.org/10.12775/SIT.2018.033
}

My argument in this essay is very simple. Legal order consists of much more than a legal system (the law): this is a non positivist approach in jurisprudence. Both the legal system and the legal order are made by many decisions of many participants and not only by the legislative authorities of the State. The wider context of the legal order and the legal system is of course a social order and the spontaneous interactions between public and private power on the one hand and public and private property on the other are the most significant sources of the dynamism of the law and the legal order. Last but not least, I want to make it clear that law and the legal order should be perceived as an emergent process of changes and not as stable and rationally designed structures. The emerging legal order and the law as its normative component is permanently driven by a competitive cooperation of many actors, by intentional decisions and actions undertaken by persons who are motivated by their concern about their legal status ${ }^{1}$.

${ }^{1}$ Full presentation of my version of the new realism in jurisprudence is provided in my recent books Status prawny i dynamika porzadku prawnego (Legal Status and the Dynamics of the Legal Order), Łódź 2017 and Teoria i filozofia prawa: wykłady (Theory and Philosophy of Law: Lectures), Gdynia 2018. 


\section{Taking legal status seriously}

The smallest element of law is a rule or a principle of required behaviour that imposes obligations or ascribes some rights or permissions to a certain category of persons who should consider those normative facts of culture as valid and binding reasons for actions. Categorization of both physical and legal persons is expressed in their legal status. It is an almost forgotten concept that we inherited from Roman jurisprudence but in the last decades legal theory has mainly focused on rights that are supposed to trump rules and principles of law and of morals.

I take human rights seriously as many liberal thinkers have rightly advised. But the legal status of a person is much more than just his or her rights. It can be defined rather as a normatively grounded set of rights and obligations of a person and a certain level of recognition of this set by other people. Therefore, the legal component of status is always accompanied by the social recognition that is a social fact which, in any circumstances, interacts with the legal normativity of rights and obligations. Convolution of facts and norms is the essence of legal status in action. Status can be achieved by a person or ascribed to them, but in any case it is a sophisticated mixture of norms and facts which I call a convolution of facts and norms.

Not only states or governments can be recognized by other states under international law, but the legal status of any person is recognized to a certain degree by other persons. If the degree of social recognition is very low, the content of the legal set of rights and obligations is affected in the social life of the law. When a degree of social recognition is very high, legal status is more robust and more deeply rooted into the cultural context of the law. It seems quite natural that people are not always satisfied with their legal status as they can perceive that they have obligations which are too many or too hard and/or not enough rights. In such a case they might wish to improve the balance of rights and obligations and have strong or at least sufficient reasons for action guided by the wish to get higher status or get a better protection of their 
present status. Those who are satisfied with their legal status may not be happy with a degree of recognition they get from others. So they could also wish to change something for the better in their social position. Therefore, the dynamics of status drives relevant changes in legal norms and in legal systems. It can lead at some point to Der Kampf ums Recht as Rudolf Jhering aptly put it in his Vienna lecture in 1872. It may happen owing to a conflict of status; persons who are pushing for change may clash with persons interested in the status quo.

My point is that the actions of many persons interested in the new balance of their legal status are the fundamental source of the dynamics of norms, of entire legal systems and of the legal orders. It is not just the will of the law-making authorities of a State but the permanent dynamism of persons under a specific legal system. Unless I am very much mistaken, what we have got here is the preliminary answer to a basic question why the legal systems and orders change, and why it is a process rather than a structure. There seems to be an explanatory capacity with respect to the concept of legal status which may help the realist jurisprudence in theory building.

There is one more advantage in focusing on legal status and not only on rights of persons. For almost 100 years, children and the youth in the West have been educated about their rights and about the history of political struggles for the development of human rights. So we keep the legal obligations and moral duties somewhere in the shade. As all comparative legal studies have proved, Oriental legal orders focus on the obligations of an individual, both moral and legal, and on a duty of self-perfection. Perhaps this mode of upbringing was conducive to the fast development which has allowed many Asian societies to catch up with the West within 40-50 years.

My idea is halfway between the liberal focus on rights alone and the Oriental focus on obligations. Legal status is a well-balanced configuration of rights and obligations and the concept of status is deeply rooted in Roman legal tradition. The answers are up to us, whether we want to continue with the rights-oriented public education or switch rather more to the concept of legal status. 
There is another good reason for the reevaluation of the legal status of persons. In a good legal order one can distinguish two aspects of the balance of rights and obligations: internal and external. Internal balance takes place within the status of a specific person between his or her rights and his or her obligations. I do not assume that the fulfillment of obligations should be a necessary condition for the enjoyment of one's rights, but that there should be a just proportion between the rights and obligations of a person and it should not be impossible for him or her to enjoy his or her rights and fulfil his or her obligations under the law.

More potential is hidden in the external balance of the legal status of many persons. If one person Alpha has a decent level of certainty that his or her rights will be taken seriously by other persons, it should be the case that many other persons duly fulfil their obligations regarding that person Alpha. If his or her rights are to be implemented erga omnes there must be billions of persons who take their rights seriously and fulfil all their obligations that are a necessary condition for keeping the rights of Alpha safe and protected. It opens an opportunity to guarantee our rights in a horizontal manner without interference from the high authority of our governments. Where most persons can and want to fulfil their legal obligations, the rights of many other persons will be protected without the vertical guarantees provided by the State. This is an external balance of legal status which can protect the rights of almost all persons under a specific legal order. If a person wants to have a solid and sound protection of their rights, they should be interested in whether the others are ready and willing to fulfil their legal obligations which hare relevant to their rights. The self-organization of societies which are taking into account the external balance of the legal status of persons seems to be a more democratic solution than a top-down institutional protection of our rights by governments and courts only. We can manage quite a lot in a horizontal manner. Yes, we can. All participants in a legal order, we can get it done by our own actions, guided by the sense of duty and serious approach to our legal obligations. It does not mean that vertical institutions protecting human rights are obsolete and useless. What is stipulated in our Constitutions, how separation 
of powers works, how the system of justice works along with the judicial review of administrative decisions, etc. still matter.

\section{Institutional framework of the social order}

The political game on social and legal status takes place in the wider context of a social order and at a certain level of cultural development. What are the most important characteristics of the social order that strongly encourage the actions of persons? My working hypothesis is that any social order has a set of structured relationships at its core which I call an institutional framework. The structured framework of a social order consists of relationships between four centres of power: public authority, private authority, public ownership and private ownership. The following models present the basic points of my argument.

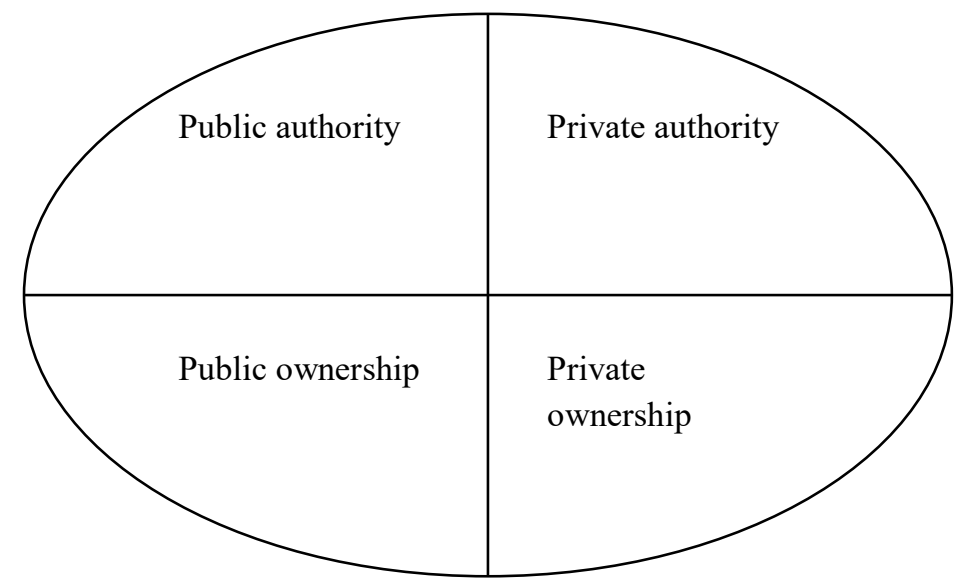

Model 1. Institutional Framework of the Social Order

An ideal balance of all centres of power is impossible because we cannot assume that all four are equally powerful and that each of them can keep an independent position from the other three. Model 1 is an idealized vision of an unreal world. But it helps understand 
the reality of unbalanced systems. The real world is unbalanced and changing in a non-linear style. In the contemporary global system public authority can be located at the global, national, regional or local level. Governments are the most active components of public authority networks, but global governance matters to such a degree that one can wonder when all governments will be captured by global superpowers which do not use legal norms in most of the cases. Global power is actually less interested in the content of the legal order than in the grand strategy based on military and economic means.

Long ago private authority was rooted in the traditional family where the father (pater familias) was a key person and the most powerful regulator. Nowadays it is rather a big business community and its leaders, and this variety of power is very much interwoven with financial institutions such as banks, investment funds, and big insurance. The bad news is that the top managers/owners of the big money who have a great deal of private authority and private wealth do not need the law as a strategic tool of their domination.

We may conclude that the institutional framework of modern and postmodern societies are dominated by elites who perceive legal systems as a secondary tool and prefer less formalized means of power. The impact of this conditio humana on legal systems and on the legal status of persons must be taken seriously into consideration by any realist school of jurisprudence. The most important decisions of the present-day grand strategy are made above the law and are hardly implemented by the courts of justice. The future of legal systems will be shaped by the choices of the giants of private power who are hardly aware of the limits set by the law and are strong enough to ignore the principles of law. What really matters to them are the rules of The Big Game which are not legal and many of them are obviously illegal. In 2017 wealth inequality in the global system reached an unprecedented level: $1 \%$ of persons owned $50.2 \%$ of the wealth available in the world ${ }^{2}$. President Obama in his last address to the United Nations rightly gave the dramatic

2 The report submitted by Oxfam to The World Economic Forum in Davos in winter 2018. Reports of Oxfam are based on data from Credit Suisse. 
warning that the world in which $1 \%$ of the population owns more than $99 \%$ of the people cannot be stable. The public interest and the common good are not protected by well-trained guards who are strong and dedicated enough to limit the concentrated power of private authority and private wealth.

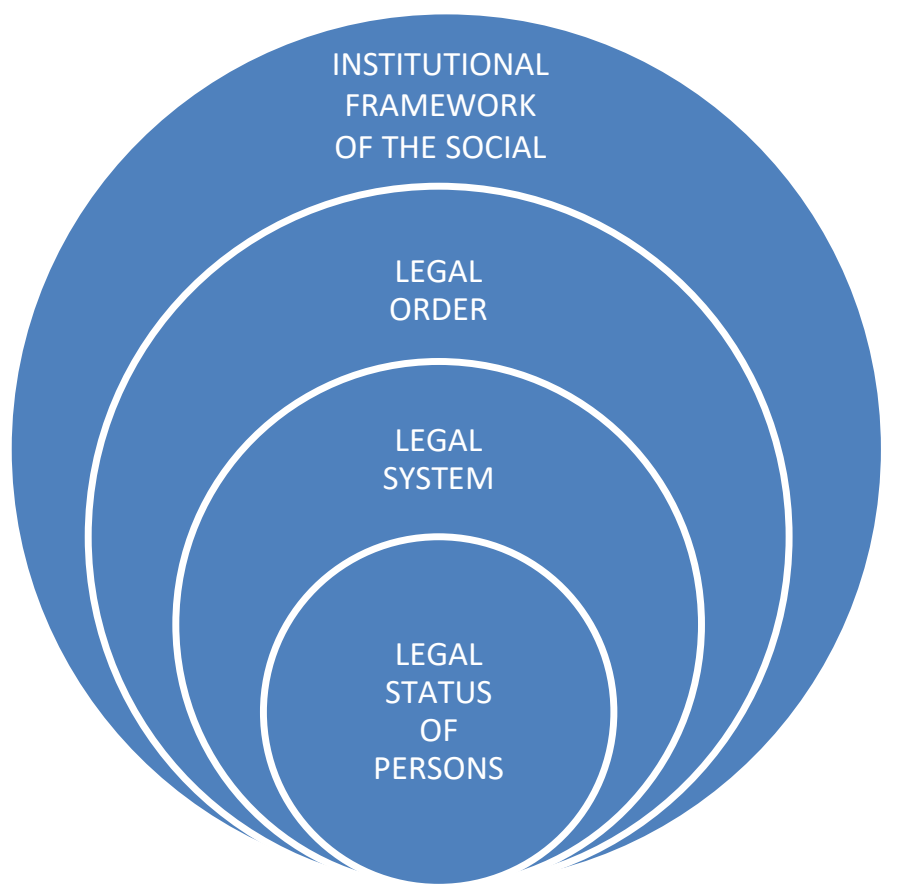

Model 2. General Model of Systemic Interactions

\section{Where Is a System Builder?}

The competition of persons in the field of their status leads to many unpredictable outcomes. But in the end we see many changes accomplished by reforms which take the shape of a truncated evolution of the legal system. A legal system may be conceived as a system of norms only (Hans Kelsen), a system of primary and secondary rules (Herbert Hart), or a system of rules, principles and 
policies (Ronald Dworkin). It can be a closed system or a system open to some moral and other normative standards which are necessary for a reasonable and just application of legal rules. Inclusive positivists, new legal realists and followers of the Dworkinian idea of the law as integrity would agree that legal systems are open to a degree to some other normative systems. My sociological intuition is very close to the above mentioned inspiring ideas of the great legal philosophers.

My question is what makes it possible for that thousands of norms coming from prescriptions enacted by parliaments and by governments, created by judicial decisions and precedents and coming from tradition etc. may form up into what we call a legal system. Who is actually a system maker who builds a big and complex whole out of small pieces of normativity dispersed in so many sources? Is it true what positivist tradition teaches us that there is a rational law making authority at the top of the political power structure which is a great system builder and later sends the systemic normative message to millions of recipients who are compelled to follow what has been decided by the unlimited wisdom and a legitimate will of legislative bodies? This top down model of communication and a model of a rational law-giver seems to be less true today than it perhaps was 100 years ago when positivist philosophy was the dominant mode of reasoning about the law.

My response to this idea is a strongly negative one. Such a huge, complex and comprehensive, all-encompassing normative system that has an efficient regulatory capacity and is valid and binding for all persons cannot be created by a fiat of a small group of legislators and their experts. There is no one single top quality mastermind somewhere over the rainbow which creates a legal system without absurdities, loopholes and contradictions. We should ask how is it that one specific legal rule or pattern of behaviour has no regulatory power but a system of such rules is quite efficient in controlling and regulating the behaviour of millions of human beings.

It is an emergent process that creates new qualities on systemic level that were absent in its own components. There are many good examples of emergence in nature. A single neuron is unable to think but a bigger system made of neurons such as our brain has 
this wonderful capacity. A single termite will not build a huge, airconditioned and well-ventilated construction of a termite mound in which millions of termites usually live. There are no designers and architects among termites, and human architects could learn quite a lot from insects. Spontaneous self-organization and the natural art of cooperation make such wonders possible. An emergent process produces a legal system through thousands of decisions made on an everyday basis by many participants. Spontaneous cooperation and competition for better status are the driving forces that make the emergence of a legal system possible.

The legal system emerges through several stages:

1. Enactment of legal prescriptions by a legislative authority of the State. This is just the beginning of the long path of system building. Positivist legal theory claims that it is enough to make a system of laws because the legislators are rational enough to be able to create a coherent system of regulations. If the emergence starts from a precedent, it is a court of justice that makes this first stage possible and the institutional legislators have nothing to do in such circumstances. This is more frequent in Common Law systems than in Civil Law systems based on the traditions of Roman law and jurisprudence.

2. Publication of normative acts such as statutes by a competent political authority that is a condition sine qua non of coming into force for all enacted normative acts of the State.

3. Reconstruction of fully fledged legal norms and legal principles from prescriptions enacted by a legislative authority (vide stage 1) and from other sources of law. This stage is dominated by judges and administrative authorities that have the power of application of the law. There are thousands of participants acting in this stage of system emergence and the legislative bodies cannot influence the final outcome of the intellectual operations of legal professionals. At this stage the law in books becomes the law in action as was explained aptly by the first generation of legal realists in the United States and in the Nordic countries. 
4. Interpretation of reconstructed norms and principles and fixing the precise meaning of these norms and principles and reasoning by analogy that will find out to what degree the meaning of the facts of the case and the meaning of norms are isomorphic. It is called syllogistic reasoning in the positivist tradition. Without the interpretation of reconstructed norms the words of the law in books could not turn into law in action. Arthur Kaufmann was convincing in arguing that a norm without interpretation cannot regulate anything and thus is not law at all. Convolution of facts and norms must be interpreted as an integral unit and properly understood by a person who is charge of law application. The facts must be interpreted as well in order to acquire a meaning relevant to a final solution of the legal problem. Bernard Baruch, one of the most successful bankers in the world's history and strategic adviser to American presidents, was right when he said that "Every man has a right to his opinion, but no man has a right to be wrong in his facts. If you get all the facts, your judgment can be right; if you don't get all the facts, it can't be right".

5. Justification of interpretations and legitimization of reconstructed norms and their meanings. Giving reasons for action that are compelling and binding presupposes providing good and robust reasons for acts of interpreting the complex convolutions of facts and norms.

6. An act of decision of law application made by the court of justice or by an administrative authority in charge of law application. Such a decision needs proper justification and the decision maker should provide robust argumentation that could be convincing to other participants of the legal order. The psychological and logical power of such an argument is crucial for the living law in action and for the real validity of such a law.

7. In this stage the applied law in action reaches the minds of many participants in the legal order and now they can make their own decisions about whether they should actually follow the law in action or object to it for some reasons. Reasons for 
obedience or disobedience may be very different as are the attitudes of human beings towards the legal system. They may be legalists, pragmatist or conformist followers of the law because their reasons for obedience are different. They may be cynical or nihilist and for these reasons prefer a disobedient mode of behaviour. Whatever they choose, their choice really matters for a process of the emergence of the legal system. Wherever anomic behaviours are widely chosen by many participants, the legal system cannot fully emerge and it exists to a lower degree than it is the case where most participants have sufficient reasons to obey the content of the law in action. The psychology of the individual is here the issue. Anomie is a situation when many people disobey the law, but they know more or less what the requirements of the law are and they are aware that they are breaking it. It may happen however that law breakers are, in a sense innocent sinners because they do not know what is legal and what is illegal, what the norm is and what an exception to it is. Such a situation may be called the destruction of normativity and it seems to be a more dangerous sickness of the legal system than a simple anomie. Cynicism and nihilism in the attitudes of participants is an obstacle in the emergence of the legal system, but it is important to take into consideration all obstacles while trying to explain the emergence of the living legal system.

\section{The legal order emerges without a single designer}

The more complex and more dynamic the legal systems are, the more we need to develop a set of wide concepts to be able to study the emerging big entities from a holistic perspective. Holism begins the study of law with bigger entities and goes later into details. For example, we start from a legal order and later we go to the specific legal norm. Reductionism starts with elements and details in order to understand big entities. For example, it starts from a single 
norm in order to understand how the legal order works. The social reality of the contemporary world encourages us to prefer a holistic methodology. Thinking big in jurisprudence requires big concepts and much more knowledge about history, politics, anthropology, sociology, and psychology than most legal scholars are ready to accept as a necessary means of understanding the laws of the present.

Emergent legal order comes into being and changes its content first of all through improvisation, incrementalism, and adaptation to changing circumstances. Its contours emerge over time instead of being planned in advance and rationally created according to some designs. Punctuated evolution prevails but there are many ups and downs on the way to a more or less coherent whole that is able to sustain and regulate social relations. Rational planning of law making is hardly possible in a world of fast and hardly predictable changes guided by swiftly moving coalitions of pressure groups and particular interests. Very frequently our elites are caught by surprise (Black Swans) and none of our strategies really operates something I called The Tsunami Effect in strategic thinking a few years ago ${ }^{3}$. There are good reasons to doubt if any social engineering through the law is still possible in such circumstances.

Legal theory and the practices of professional lawyers will be better served by a wider concept of the legal order. It should not be just a linguistic equivalent to a legal system as it happens very frequently in discourses about the law. I propose a wide meaning of the legal order which consists of the following components:

1. The legal system and its axiological foundation. Values shared by persons and social groups have a strong impact on the normative content of legal rules, principles, and policies. The influence of religious beliefs and doctrines on the content of a legal system must be taken seriously into consideration because the perfect autonomy of the law is hardly possible in contemporary societies and it is almost impossible in many societies which are still living in pre-modern civilizations.

${ }^{3}$ W. Lamentowicz, Strategia państwa: teoria państwa aktywnego wobec sił spontanicznych, Warszawa 2015. 
2. The entire network of legal relations between participants (physical and legal persons and public authorities of the State) who are concerned with their own legal status. Any social interaction between participants that is regulated by legal rules and principles belongs to a legal order.

3. Legal professions, their status and ways of recruitment, the type of education and experience that is required from judges and other practitioners of law. An interpretative community of professional lawyers is an indispensable element of a legal order. There is no order without well-trained guardians of an order who are the persons of integrity and who take care about the consistency, coherence and the moral quality of the law in action. If a legal order should be a just order, then there must be persons who cultivate the idea of justice and who know how to protect justice by legal means. I assume it is a moral duty of all professional lawyers.

4. Methods of legal reasoning and law interpretation that are widely used in the process of turning the law in books into the law in action. It is important to determine the extent to which a simple linear interpretation, circular hermeneutical thinking, and argumentation theory are actually used by all persons in charge of law implementation and by the judges in particular. What really is interpreted are just the words of prescriptions in the normative acts of a political will, norms and principles reconstructed from many sources or convolutions of legal norms and facts of a case under consideration.

5. Style of law execution (executio iuris) in a broad sense can be defined by the level of the rigidity of law, types of punishments in criminal law, rights of the accused and imprisoned persons, normative limits to the use of violent means by the state authorities, and many other indicators.

6. How the legal status of all participants is institutionally protected in a specific legal order? Is there is a proper balance of rights and obligations in legal relationships? Is there a sustainable harmony of mutual recognition of that legal status? In order to know this one should include the allencompassing network of legal relations into the wide concept 
of the legal order. Legal orders consist of human beings and their interactions which are regulated by the law or at least tolerated by the law.

7. Living memory of legal traditions, legal habits and patterns of behaviour which are deeply rooted into the culture by a long lasting experience. As Roman jurisprudence believed, usus longaevus really matters and it may live much longer than many lawyers could imagine.

8. Structure and frequency of attitudes toward the legal system among the participants of the legal order. Attitudes are usually regarded as part of the institutionally protected culture, but I suggest that this psychological and cultural background be considered as part of the legal order as well. Legal order without values and without other cultural ingredients would be very "thin" in both a sociological and a moral sense. Real legal orders are robust or "thick" because our laws are made by human beings for human beings. Legal orders differ very much in terms of the proportion of nihilist and cynical attitudes toward the law. Nihilists and cynics are more inclined to disobedience than legalists who follow the law as a matter of principle as they assume the law is good or those persons who follow the law due to its instrumental value only. These participants obey the law because the law is followed by their group of reference which sets valid patterns of behaviour for other people or because obedience to the law brings some benefits to the followers.

That is another good reason to stop calling all of us "addressee of norms" as the positivist school in jurisprudence used to teach many generations of lawyers. This was a vision of law as a topbottom hierarchy in which a rational law maker is at the top and they send normative messages to all persons who are just addressees of messages of the power centre. Those persons are required to obey and not to participate in the legal order.

A non-positivist and realist proposition that I share is based on a vision of a horizontal community, a modern civil society of citizens who are equal before the law. In such a community any person (physical or legal) and any public authority of the State that 
has legal status under a specific legal system will be regarded as a participant in a legal order, and not just as somebody who receives letters with norms and directives from the top of the power structure.

Big legal order must be inclusive; otherwise it will be dead very soon. That means that there should be fewer and fewer persons who are a variety of homo sacer, who are outlaws deprived of their legal status and whose life is reduced only to biological existence outside the legal order ${ }^{4}$.

\section{Conclusions}

An emergent process brings about a coherent legal system and a dynamic legal order. There are many participants who contribute their energy and interests to this spontaneous process - from those who are dissatisfied with their legal status to those who are at the top of the hierarchy of authority and wealth. But even the weakest and the poorest are included into this process of emergence and not everything can be decided by the richer and the most powerful members of the golden one percent, by the members of the global elite. Participants in the legal order, both rich and poor, powerful and having a mediocre power, are concerned about their legal status. Actions driven by these concerns foster changes of the smallest components such as specific norms and meanings of these norms in relation to facts of social life. In this way the emergence is fuelled by changes in small elements that in the long run influence the features of the legal system as an interacting whole.

On the other hand, two bigger systems - the institutional framework of the social order and the legal order - exert an influence on the legal system as well. This is depicted in the General Model of Systemic Interactions (model 2). The interactions between the

${ }^{4}$ G. Agamben elaborated the semantic distinction made by Aristotle between $\zeta \omega n$ Zoi (biological existence similar to the life of plants and animals) and ßíos Bios (life in a human made culture, life that is protected by a legal status). G. Agamben, Homo Sacer: Sovereign Power and Bare Life, Stanford, CA 1998. 
three big entities define the chances and opportunities of participants and their legal status, of course. For some participants it is beneficial while for others it can be detrimental.

So the overall structure of status is to a great extent determined by three big systems (legal system, legal order, and the institutional framework of the social order) and by the interplay of social energies engaged in each of them. The systemic determination of all efforts in the field of status imposes some limits on persons and provides some new opportunities. There are winners and losers in this game. Losers are many and winners are few. Owing to this asymmetric outcome of the status game, the three big systems must change. If the power elite freeze the adaptation and refuse to reform the legal system and the legal order, the risk of rebellion or at least a wave of social protest may increase. The frustrated expectations of the losers and the lack of a decent balance in the field of statuses never stop pushing for change. Human hope for a better social and legal status never dies. Emerging legal orders are always full of human energy and human hopes for development. The dynamics of norms and normative systems will never stop and the final outcome is hardly predictable owing to the emergent characteristics of this process.

\section{STRESZCZENIE}

Emergencja porządku prawnego

Dowodzę, że porządek prawny jest znacznie większą całością niż system prawa. Porządek ten nie jest tworzony wyłącznie przez najwyższą władzę prawodawczą. Wyłania się on $z$ decyzji i działań wielu uczestników, a nie jest racjonalnie zbudowany przez nadzwyczajnego projektanta. Szersze pojęcie porządku prawnego obejmuje: emergentny system prawa, wszystkie stosunki prawne między uczestnikami zainteresowanymi własnym statusem prawnym i społecznym uznaniem tego statusu, zawody prawnicze i metody kształcenia, rekrutacji i awansowania prawników świadczących usługi w przekształcaniu prawa $\mathrm{w}$ książkach $\mathrm{w}$ prawo $\mathrm{w}$ działaniu, stosowane metody interpretacji faktów i norm oraz metody argumentacji na rzecz określonych rozwiązań problemów prawnych, style egzekucji prawa, wewnętrzna i zewnętrzna równowaga statusów prawnych, żywe 
tradycje i pamięć dotyczące emergencji i stosowania prawa, a także nie najmniej ważna konfiguracja postaw społecznych wobec systemu prawa. Powinno się badać jako całość wszystko, co jest niezbędne do wprawiania w ruch żywego prawa w działaniu i jego zdolności regulowania ludzkiego zachowania. Taka holistyczna metodologia wymaga szerszych pojęć takich jak porządek prawny w szerokim znaczeniu.

Moją drugą tezą jest, że dynamika porządków prawnych jest uwarunkowana przez szersze ramy instytucjonalne ładu społecznego i przez nieustającą grę interesów związanych ze statusami prawnymi wszystkich uczestników porządku prawnego.

Słowa kluczowe: emergencja; system prawa; ramy instytucjonalne ładu społecznego; władza prywatna; własność prywatna

\section{SUMMARY}

\section{The Emergence of the Legal Order}

I argue that the legal order is a much bigger entity than a legal system. It is not made by the highest legislative authority alone. It emerges from the decisions and actions of many participants instead of being rationally constructed by a super designer. The wider concept of the legal order embraces: the emergent legal system, all legal relations between participants who are concerned with their own legal status and a social recognition of this status, the legal professions and the methods of their education, recruitment and promotion in their service of transforming the law in books into the law in action, methods of interpretation of facts and laws and methods of argumentation in favour of some solutions of legal problems, styles of law execution, internal and external balance of legal status, living traditions and memories relevant to the emergence and implementation of the law, and last but not least, the configuration of attitudes toward the legal system. Everything that is indispensable for putting in motion the living law in action and its capacity to regulate the human behaviour will be studied as a whole. This holistic methodology requires broader concepts such as the legal order in a wide sense.

My second point is that the dynamics of legal orders is driven by the wider institutional framework of the social order and by the ongoing game of interests related to the legal status of all participants.

Keywords: emergence; legal system; legal order; institutional framework of the social order; private authority; private ownership 
$176 \quad$ Wojciech Lamentowicz

\section{BIBLIOGRAPHY}

Agamben G., Homo Sacer: Sovereign Power and Bare Life, Stanford, CA 1998.

Lamentowicz W., Strategia państwa: teoria państwa aktywnego wobec sił spontanicznych, Warszawa 2015.

Lamentowicz W., Status prawny i dynamika porzadku prawnego, Łódź 2017.

Lamentowicz W., Teoria i filozofia prawa: wykłady, Gdynia 2018. 